\title{
Genetics of Synucleinopathies
}

\author{
Robert L. Nussbaum \\ Volunteer Clinical Faculty, UCSF School of Medicine, University of California, San Francisco, \\ San Francisco, California 94143 \\ Correspondence: robert.nussbaum@ucsf.edu
}

Parkinson's disease (PD), diffuse Lewy body disease (DLBD), and multiple system atrophy (MSA) constitute the three major neurodegenerative disorders referred to as synucleinopathies because both genetic and pathological results implicate the $\alpha$-synuclein protein in their pathogenesis. PD and DLBD are recognized as closely related diseases with substantial clinical and pathological overlap. MSA, on the other hand, has a distinctive clinical presentation and neuropathological profile. In this review, we will summarize the evidence linking $\alpha$-synuclein to these three disorders. Hundreds of patients with point or copy number mutations in the gene encoding $\alpha$-synuclein, $S N C A$, have been reported in the literature in association with hereditary, autosomal dominant forms of PD, DLBD, or neurodegenerative disease with parkinsonism. The copy number mutations show a dosage effect with age at onset and severity correlating with the number of extra copies of SNCA a patient carries. Common variation in and around the SNCA gene has also been found by genome-wide association studies to be associated with increased risk for apparently sporadic PD, with some evidence that these variants exert their effect through modest increases in $\alpha$-synuclein expression. Complementing the genetic evidence linking $\alpha$-synuclein to PD and DLBD is the pathological finding that $\alpha$-synuclein is a major constituent of Lewy bodies and Lewy neurites in the brains of patients with the common sporadic form of PD. On the other hand, there is little genetic evidence linking SNCA to MSA despite strong neuropathological evidence of $\alpha$-synuclein aggregation in oligodendroglial cells in MSA patients. Evidence is now emerging that $\alpha$-synuclein aggregates can have different protein conformations, referred to as strains, similar to what has been shown in prion disease. The different phenotypes in hereditary PD/ DLBD versus MSA are likely, therefore, to be the result not only of how specific mutations affect protein expression and turnover, but also a more complex interaction between intrinsic and extrinsic factors governing aggregation and strain formation.

Patsen arkinson disease's (PD), diffuse Lewy body disease (DLBD), and multiple system atrophy (MSA) constitute the three major neurodegenerative disorders referred to as synucleinopathies because both genetic and pathological evidence implicates the $\alpha$-synuclein protein in their pathogenesis (McCann et al. 2014; Burré et al. 2017). PD and DLBD are recognized as closely related diseases with substantial clinical and pathological overlap (Lippa et al. 2007). MSA, on the other hand, has a distinctive clinical presentation and neuropathological profile (Wenning and Krismer 2013; Woerman et al. 2017). In this review, we summarize the

Editor: Stanley B. Prusiner

Additional Perspectives on Prion Diseases available at www.perspectivesinmedicine.org

Copyright (C) 2018 Cold Spring Harbor Laboratory Press; all rights reserved; doi: 10.1101/cshperspect.a024109

Cite this article as Cold Spring Harb Perspect Med 2018;8:a024109 


\section{R.L. Nussbaum}

evidence linking $\alpha$-synuclein to these three disorders.

\section{MENDELIAN FORMS OF PD CAUSED BY $\alpha$-SYNUCLEIN GENE MUTATIONS}

Mutations in the gene encoding $\alpha$-synuclein were first shown to cause hereditary PD two decades ago as the result of a genetic linkage study and positional cloning effort in the large "Contursi kindred" with autosomal dominant PD and Lewy body dementia (Polymeropoulos et al. 1996, 1997). In this family, a missense mutation, p.A53T, was found to segregate with the disease. The $\alpha$-synuclein protein (encoded by the SNCA gene) had been described a few years earlier. It had originally been called nonamyloid component of plaque (NACP), because it had been isolated from amyloid plaques derived from brain tissue from patients with Alz- heimer's disease (Ueda et al. 1993; Yoshimoto et al. 1995).

In the years following the initial discovery of the p.A53T mutation in SNCA in the Contursi kindred, additional point and copy number mutations were discovered in association with hereditary forms of PD, Lewy body dementia, and other neurodegenerative syndromes that include parkinsonism, all inherited in an autosomal dominant Mendelian pattern (Fig. 1) (Krüger et al. 2001; Singleton et al. 2003; Chartier-Harlin et al. 2004; Ibáñez et al. 2004; Zarranz et al. 2004; Appel-Cresswell et al. 2013; Lesage et al. 2013; Pasanen et al. 2014; Petrucci et al. 2016). Hundreds of patients with point or copy number mutations in SNCA have been reported in the literature in association with a phenotype of PD, Lewy body dementia, or neurodegenerative disease with parkinsonism (Tambasco et al. 2016).

A

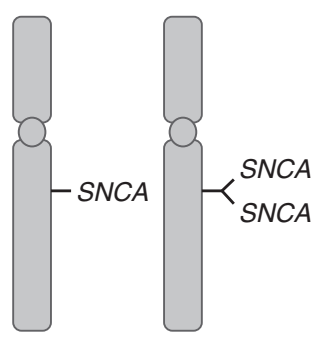

Copy number $=3 x$ Heterozygous duplication
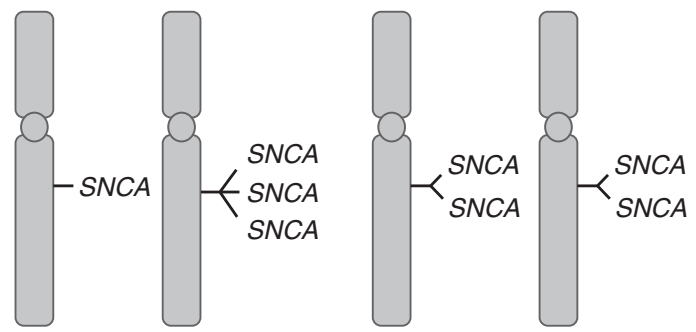

Copy number $=4 \times$ Heterozygous triplication or homozygous duplication

B

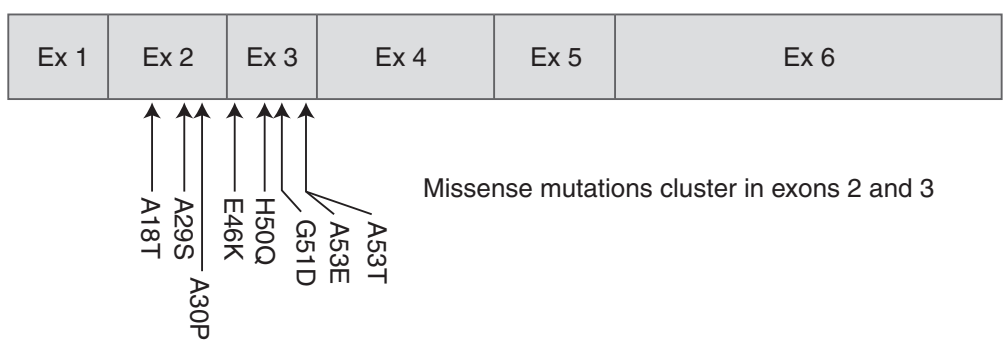

Figure 1. Schematic diagram of mutations in the SNCA gene causing Parkinson's disease (PD) and diffuse Lewy body disease (DLBD). (A) Chromosome 4 showing location of the SNCA gene on 4q. Copy number mutations are shown that are either tandem duplications or triplications of the SNCA gene, resulting in patients with either three or four copies of the gene. (B) Schematic diagram of the SNCA mRNA showing exon boundaries. Arrows indicate the locations of eight well-established point mutations that cause PD, DLBD, or other neurodegenerative disorders in which parkinsonism is a major characteristic of the disease. 


\section{THE $\alpha$-SYNUCLEIN PROTEIN IS INVOLVED IN THE NEUROPATHOLOGY SEEN IN PD PATIENTS}

Complementing the genetic evidence linking $\alpha$-synuclein to PD is a wealth of neuropathological evidence that the protein is involved in PD and DLBD pathogenesis. For more than a century, Lewy bodies (LBs) and Lewy neurites (LNs), the protein aggregates found in the brains of PD and DLBD patients, have been considered pathognomonic (Pollanen et al. 1993). The discovery of mutations in SNCA in hereditary PD was quickly followed by evidence that $\alpha$-synuclein is a major constituent of LBs and LNs in the brains of patients with PD (Spillantini et al. 1997; Poulopoulos et al. 2012). Involvement of $\alpha$-synuclein in LB and LN pathology is not, however, restricted to patients with SNCA mutations causing autosomal dominant PD. In fact, the original demonstration that LBs and LNs contained $\alpha$-synuclein aggregates was performed in patients with sporadic PD, with no SNCA mutations present (Spillantini et al. 1997). These discoveries together strongly supported a role for $\alpha$-synuclein in most hereditary as well as the common sporadic forms of $\mathrm{PD}$. What still remains unexplained is why $\alpha$-synuclein, which is normally phosphorylated on a number of serines, particularly the serine residue at position 129 , in perhaps $\sim 5 \%$ of the total $\alpha$-synuclein in neurons, is nearly $100 \%$ phosphorylated on these serines when present in LBs (Fujiwara et al. 2002; Hasegawa et al. 2002).

\section{DISEASE PHENOTYPE IN MENDELIAN FORMS OF PD: COPY NUMBER MUTATIONS}

It is well established that PD has a highly variable phenotype, with a wide range of age at onset and progression of motor and nonmotor signs (Hoehn and Yahr 1991; Chen et al. 2013). For the purposes of this review, however, it is particularly interesting to compare the phenotypes of patients with hereditary $\mathrm{PD}$ due to an SNCA mutation. In particular, what can we learn by comparing the phenotypes of individ- uals with the same mutation in different families, or even from within the same family?

More than one hundred patients have been described with copy number mutations, duplications, or triplications of the region on chromosome 4q containing the SNCA gene, resulting in individuals carrying either a total of three or four copies of an otherwise normal SNCA gene (Fig. 1A) (Konno et al. 2016). Copy number changes correlate with increased SNCA mRNA and increased $\alpha$-synuclein protein production, indicating there is little or no feedback to limit production by downregulating gene expression (Singleton et al. 2003). Compared with patients with three copies of the SNCA gene, patients with four copies (either heterozygous for a triplication or homozygous for duplication) have an $\sim 10$ yr earlier age at onset and a more rapid progression, they more frequently demonstrate myoclonus, and they show more severe cognitive impairment and psychiatric disturbances (Fig. 2). Among patients with three copies, phenotype is still highly variable, even among affected individuals from within the same family. In these cases, phenotype ranges from one that is similar to, but less severe than, the phenotype that occurs in patients with four copies to one that is indistinguishable from common, sporadic PD (Elia et al. 2013; Konno et al. 2016).

The most important conclusion to draw from these observations on SNCA copy number variants is that the phenotype in patients with four copies is more severe than in patients with three copies. This finding supports the concept of a "dosage effect," in which the more copies of SNCA that are present, the earlier the onset, the more rapidly progressive and the more severe the disease. This conclusion is supported by a fascinating historical study of a large, multigenerational Swedish family in which both duplications and triplications of SNCA were found to cause autosomal dominant $\mathrm{PD}$. In previous generations of this same family, however, an apparently recessive form of a progressive infantile myoclonic epilepsy, Unverricht-Lundborg disease (ULD) was described. Based on pedigree analysis, the investigators surmise that ULD is likely a severe manifestation of a patient having 
R.L. Nussbaum

\begin{tabular}{|l|l|l|l|l|l|l|l|l|}
\hline & A30P & H50Q & E46K & $\begin{array}{c}\text { 3 SNCA } \\
\text { copies }\end{array}$ & A53E & A53T & $\begin{array}{c}\text { S SNA } \\
\text { copies }\end{array}$ & G51D \\
\hline Age at onset & & & & & & & \\
\hline $\begin{array}{l}\text { Disease } \\
\text { duration }\end{array}$ & & & & & & \\
\hline $\begin{array}{l}\text { Cognitive } \\
\text { impairment }\end{array}$ & & & & & & \\
\hline $\begin{array}{l}\text { Psychiatric } \\
\text { disturbance }\end{array}$ & & & & & & \\
\hline Hallucinations & & & & & & & \\
\hline $\begin{array}{l}\text { Autonomic } \\
\text { dysfunction }\end{array}$ & & & & & & & \\
\hline Myoclonus & & & & & & & \\
\hline Pyramidal signs & & & & & & & \\
\hline Epilepsy & & & & & & & \\
\hline
\end{tabular}

Figure 2. Outline of clinical features associated with pathogenic SNCA mutations. Color scale from white to black is intended to denote increasing severity. For age at onset: (white) $>60 \mathrm{yr}$, (gray) between 40 and $60 \mathrm{yr}$, and (black) $<40 \mathrm{yr}$; for disease duration: (white) $>15 \mathrm{yr}$, (gray) between 10 and $15 \mathrm{yr}$, and (black) $<10 \mathrm{yr}$; for all other features: (white) absent, (gray) occasionally present, and (black) constantly present. Mutations are ordered from mildest (left) to most severe (right). (Reprinted, with permission, from Petrucci et al. 2016, (C) 2016 Elsevier.)

as many as five or six copies of the SNCA gene, suggesting an even greater $S N C A$ dosage effect (Puschmann et al. 2009). Thus, although substantial variability occurs among patients with three or four copies of the SNCA gene, even within the same family, there is a strong trend toward disease severity being proportional to the number of extra copies of $S N C A$ a patient carries. Nonetheless, the variability in disease presentation between individuals with the same mutation, even from within the same family, indicates that additional effects on the ultimate outcome of disease must result from variants at other genes, environment, or chance.

The phenotype in patients with copy number mutations strongly suggests that excessive amounts of $\alpha$-synuclein protein can initiate the process that leads to PD. Numerous studies examining the solubility of $\alpha$-synuclein have shown that the normal concentration of $\alpha$-synuclein actually exceeds its predicted limiting concentration (Baldwin et al. 2011; Knowles et al. 2014). Increasing the levels of $\alpha$-synuclein would therefore exacerbate the solubility problem and drive more protein into insoluble aggregates. Exactly what form these aggregates take in vivo during the pathogenesis of PD and what role they play in neuronal dysfunction and death is still the subject of intensive research.

\section{DISEASE PHENOTYPE IN MENDELIAN FORMS OF PD: MISSENSE MUTATIONS}

A recent review of the phenotypes reported in patients with SNCA missense mutations (A53T, A30P, E46K, H50Q, and G51D) (Fig. 1B) provides a more complex picture than the features apparent in patients with copy number mutations (Tambasco et al. 2016). Although the average age at onset for all point mutation patients is similar, $47.6 \pm 12.9 \mathrm{yr}$, tremor was found in 
$<10 \%$ of A53T, A30P, E46K, and G51D patients but found in nearly $100 \%$ of the small number of H50Q patients reported. Sleep disturbances were found to be especially prominent in E46K patients, whereas psychiatric abnormalities such as depression, anxiety, and psychosis were rare in A53T, A30P, E46K, and H50Q patients but were present in one-third to two-thirds of G51D patients. Patients with the A53E mutation have an even more unusual phenotype. The index case presented in the fourth decade with parkinsonism, insomnia, hypotension, profound spasticity, myoclonic jerks, anxiety, and panic disorder that lasted for $24 \mathrm{yr}$ until her death. She was partially responsive to levodopa and was remarkably free of hallucinations or other signs typical of DLBD (Mark et al. 1996). Point mutations in SNCA that cause parkinsonism (Fig. 1B) cluster in exons 2 and 3, which encode an $\alpha$ helical domain with lipid binding activity and a hydrophobic domain (George 2002). It is very likely that these point mutations prolong $\alpha$-synuclein half-life (Cuervo et al. 2004; Fishbein et al. 2014) by interfering with lysosomal degradation (Fraidi et al. 2016). Furthermore, in vitro and animal model evidence indicates an increased tendency for certain mutant forms of $\alpha$-synuclein to undergo accelerated aggregation and to recruit tau into inclusions compared with the wild-type protein (Narhi et al. 1999; Guo et al. 2013; Peelaerts and Baekelandt 2016; Petrucci et al. 2016). Further investigation will be required to determine whether the variability in phenotype seen with the different missense mutations indicate that these various point mutations have additional toxic gain-of-function effects that go beyond simply prolonging the half-life of the protein.

\section{ROLE OF SNCA VARIATION IN SPORADIC PD}

Copy number variants that result in a $50 \%-$ $100 \%$ increase in the production of wild-type $\alpha$-synuclein protein cause autosomal dominant $\mathrm{PD}$, with variation in the severity of phenotype consistent with a dosage effect. This observation then begs the question as to whether common variation in the population could be re- sponsible for more modest increases in $\alpha$ synuclein expression that might then contribute, as one factor among many, to the pathogenesis of apparently sporadic PD. Linkage analysis in families is not capable of finding such effects; therefore, all insights into a genetic contribution to a multifactorial etiology for PD have come from genome-wide association studies (GWAS).

Soon after the discovery of the role of the SNCA locus in hereditary PD, common variants at this locus were tested for association with sporadic PD. A positive association was seen between PD and expanded alleles at an imperfect repeat, NACP-Rep1, located $\sim 10 \mathrm{~kb}$ upstream of the transcriptional start site of SNCA (Tan et al. 2000; Farrer et al. 2001). Many additional GWAS analyses since then (Satake et al. 2009; Simón-Sánchez et al. 2009; Mata et al. 2011) have supported a statistically significant association between the risk for PD and a number of single-nucleotide polymorphism (SNP) alleles located both at the $5^{\prime}$ end and the $3^{\prime}$ end of the SNCA gene. The last 15 years of GWAS studies have been recently summarized in a meta-analysis involving discovery cohorts of 13,708 PD cases and 95,282 controls and more than 5000 cases and controls designed for replication. An association between PD and two dozen SNP loci reached genome-wide significance and could be replicated (Nalls et al. 2014). SNCA variants are highly associated with PD, with an effect size (odds ratio) of 1.3-fold that was highly statistically significant $\left(P=4.16 \times 10^{-73}\right)$. Although the effect size of each of the two dozen replicated associated alleles was individually small, the cumulative risk was substantial. Individuals with alleles that put them in the highest and lowest quintiles of genetic risk differed in their odds of PD 3.31-fold (95\% confidence interval 2.55-4.30; $P=2 \times$ $\left.10^{-16}\right)$. In addition to the significant association of alleles at the SNCA locus to PD risk, there is also strong evidence for at least two linkage disequilibrium blocks located at either end of the gene, each of which independently contributes to disease risk.

In support of the hypothesis that common variants might contribute to PD risk through 
upregulation of SNCA expression, the same NACP-Rep1 alleles associated with an increased risk for PD were shown to increase $\alpha$-synuclein expression in a transgenic mouse model containing artificial bacterial chromosomes containing the human SNCA gene engineered to have the different NACP1-Rep1 alleles (Cronin et al. 2009). More recent studies of an SNCA SNP locus, rs356168, deserve particular mention. This SNP, located within the fourth intron of SNCA, resides within an intronic enhancer DNA sequence that binds transcription factors. Genome editing was used to create neurons derived from induced pluripotent stem cells that differed only in whether they carried the risk allele $(\mathrm{G})$ or the protective allele $(\mathrm{A})$ at rs356168. An SNCA gene with the G allele at rs356168 resulted in a highly significant increase in expression of $\alpha$-synuclein over an SNCA gene containing the A allele at this SNP locus. The G allele was further shown to have reduced binding of two transcriptional repressors, EMX2 and NKX6-1, therefore allowing enhanced expression of the gene. These data indicate a direct functional relationship between an allele that is associated with an increased risk for PD, reduced binding of repressor transcription factors to the risk allele, and increased SNCA expression. This finding supports the hypothesis that common variation at the SNCA locus that increases $\alpha$-synuclein expression also increases the risk for apparently sporadic PD.

\section{MULTIPLE SYSTEM ATROPHY}

Multiple system atrophy (MSA) is a rapidly progressive, lethal neurodegenerative disorder characterized by progressive autonomic failure, parkinsonism that is minimally responsive to levodopa, and cerebellar ataxia (Woerman et al. 2017). In contrast to the genetic evidence linking mutations in the $\alpha$-synuclein gene to Mendelian forms of hereditary PD and the convincing association of common polymorphic variants in the SNCA gene with sporadic PD, there is little genetic evidence linking SNCA to MSA. One exception is a patient with a newly described A53E mutation in SNCA, in which neuropathology showed lesions consis- tent with both MSA and PD (Pasanen et al. 2014). Nonetheless, the role of $\alpha$-synuclein aggregation in MSA is strongly supported by the presence of $\alpha$-synuclein aggregates in oligodendroglial cells in the central nervous system and autonomic ganglia of MSA patients, reported just a few years after the discovery of $\alpha$-synuclein aggregates in Lewy bodies in PD and DLBD patients (Spillantini et al. 1998; Wakabayashi et al. 1998). This is a striking finding because oligodendroglial cells express little to no $\alpha$-synuclein under normal conditions. The pathological appearance of the aggregates in MSA is different from the LB and LN pathology in PD and DLBD, and the protein in MSA appears to have a different conformation and solubility profile (Duda et al. 2000; Campbell et al. 2001; Prusiner et al. 2015).

\section{CONCLUSION}

$\alpha$-Synuclein plays a central role in the pathogenesis of all three synucleinopathies. In PD and DLBD, there is abundant genetic evidence supporting the hypothesis that increased levels of the protein caused by overexpression and/or reduced turnover leads to the formation of a variety of different insoluble aggregates in neurons and astrocytes, which, in turn, cause dysfunction, toxicity, and cell death. MSA, on the other hand, is almost never inherited and is characterized by oligodendroglial involvement with a rapid course. Evidence is now emerging that $\alpha$-synuclein aggregates can have different protein conformations, referred to as strains (Peelaerts and Baekelandt 2016), similar to what has been shown in prion disease (Safar et al. 1998). The different phenotypes in hereditary PD/DLBD versus MSA are likely, therefore, to be the result not only of how specific mutations affect protein expression and turnover, but also a more complex interaction between intrinsic and extrinsic factors governing strain formation. In turn, different strains likely contribute, along with other factors, to the types of cells affected, the tissues and anatomic structures that are ultimately impacted by aggregation, and the resulting disease phenotype observed in patients. 


\section{REFERENCES}

${ }^{*}$ Reference is also in this collection.

Appel-Cresswell S, Vilarino-Guell C, Encarnacion M, Sherman H, Yu I, Shah B, Weir D, Thompson C, Szu-Tu C, Trinh J, et al. 2013. $\alpha$-Synuclein p.H50Q, a novel pathogenic mutation for Parkinson's disease. Mov Disord 28: 811-813.

Baldwin AJ, Knowles TP, Tartaglia GG, Fitzpatrick AW, Devlin GL, Shammas SL, Waudby CA, Mossuto MF, Meehan S, Gras SL, et al. 2011. Metastability of native proteins and the phenomenon of amyloid formation. J Am Chem Soc 133: $14160-14163$.

* Burré J, Sharma M, Südhof TC. 2017. Cell biology and pathophysiology of $\alpha$-synuclein. Cold Spring Harb Perspect Med doi: 10.1101/cshperspect.a024091.

Campbell BC, McLean CA, Culvenor JG, Gai WP, Blumbergs PC, Jäkälä P, Beyreuther K, Masters CL, Li QX. 2001. The solubility of $\alpha$-synuclein in multiple system atrophy differs from that of dementia with Lewy bodies and Parkinson's disease. J Neurochem 76: 87-96.

Chartier-Harlin MC, Kachergus J, Roumier C, Mouroux V, Douay X, Lincoln S, Levecque C, Larvor L, Andrieux J, Hulihan M, et al. 2004. $\alpha$-Synuclein locus duplication as a cause of familial Parkinson's disease. Lancet 364: 11671169.

Chen H, Burton EA, Ross GW, Huang X, Savica R, Abbott RD, Ascherio A, Caviness JN, Gao X, Gray KA, et al. 2013. Research on the premotor symptoms of Parkinson's disease: Clinical and etiological implications. Environ Health Perspect 121: 1245-1252.

Cronin KD, Ge D, Manninger P, Linnertz C, Rossoshek A, Orrison BM, Bernard DJ, El-Agnaf OM, Schlossmacher MG, Nussbaum RL, et al. 2009. Expansion of the Parkinson disease-associated SNCA-Rep1 allele upregulates human $\alpha$-synuclein in transgenic mouse brain. Hum Mol Genet 18: 3274-3285.

Cuervo AM, Stefanis L, Fredenburg R, Lansbury PT, Sulzer D. 2004. Impaired degradation of mutant $\alpha$-synuclein by chaperone-mediated autophagy. Science 305: 12921295 .

Duda JE, Giasson BI, Gur TL, Montine TJ, Robertson D, Biaggioni I, Hurtig HI, Stern MB, Gollomp SM, Grossman M, et al. 2000. Immunohistochemical and biochemical studies demonstrate a distinct profile of $\alpha$-synuclein permutations in multiple system atrophy. J Neuropathol Exp Neurol 59: 830-841.

Elia AE, Petrucci S, Fasano A, Guidi M, Valbonesi S, Bernardini L, Consoli F, Ferraris A, Albanese A, Valente EM. 2013. $\alpha$-Synuclein gene duplication: Marked intrafamilial variability in two novel pedigrees. Mov Disord 28: 813-817.

Farrer M, Maraganore DM, Lockhart P, Singleton A, Lesnick TG, de Andrade M, West A, de Silva R, Hardy J, Hernandez D. 2001. $\alpha$-Synuclein gene haplotypes are associated with Parkinson's disease. Hum Mol Genet 10: 1847-1851.

Fishbein I, Kuo YM, Giasson BI, Nussbaum RL. 2014. Augmentation of phenotype in a transgenic Parkinson mouse heterozygous for a Gaucher mutation. Brain 137: 3235 3247.
Fraidi A, Klein AD, Medina DL, Settembre C. 2016. Brain disorders due to lysosomal dysfunction. Annu Rev Neurosci 39: 277-295.

Fujiwara H, Hasegawa M, Dohmae N, Kawashima A, Masliah E, Goldberg MS, Shen J, Takio K, Iwatsubo T. 2002. $\alpha$-Synuclein is phosphorylated in synucleinopathy lesions. Nat Cell Biol 4: 160-164.

George JM. 2002. The synucleins. Genome Biol 3: reviews 3002 .

Guo JL, Covell DJ, Daniels JP, Iba M, Stieber A, Zhang B, Riddle DM, Kwong LK, Xu Y, Trojanowski JQ, et al. 2013. Distinct $\alpha$-synuclein strains differentially promote tau inclusions in neurons. Cell 154: 103-117.

Hasegawa M, Fujiwara H, Nonaka T, Wakabayashi K, Takahashi H, Lee VM, Trojanowski JQ, Mann D, Iwatsubo T. 2002. Phosphorylated $\alpha$-synuclein is ubiquitinated in $\alpha$ synucleinopathy lesions. J Biol Chem 277: 49071-49076.

Hoehn MM, Yahr MD. 1991. Parkinsonism: Onset, progression, and mortality. 1967. Neurology 57: S11-S26.

Ibáñez P, Bonnet AM, Débarges B, Lohmann E, Tison F, Pollak P, Agid Y, Dürr A, Brice A. 2004. Causal relation between $\alpha$-synuclein gene duplication and familial Parkinson's disease. Lancet 364: 1169-1171.

Knowles TP, Vendruscolo M, Dobson CM. 2014. The amyloid state and its association with protein misfolding diseases. Nat Rev Mol Cell Biol 15: 384-396.

Konno T, Ross OA, Puschmann A, Dickson DW, Wszolek ZK. 2016. Autosomal dominant Parkinson's disease caused by SNCA duplications. Parkinsonism Relat Disord 22: $\mathrm{S} 1-\mathrm{S} 6$.

Krüger R, Kuhn W, Leenders KL, Sprengelmeyer R, Müller T, Woitalla D, Portman AT, Maguire RP, Veenma L, Schröder U, et al. 2001. Familial parkinsonism with synuclein pathology: Clinical and PET studies of A30P mutation carriers. Neurology 56: 1355-1362.

Lesage S, Anheim M, Letournel F, Bousset L, Honoré A, Rozas N, Pieri L, Madiona K, Dürr A, Melki R, et al. 2013. G51D $\alpha$-synuclein mutation causes a novel parkinsonian-pyramidal syndrome. Ann Neurol 73: 459-471.

Lippa CF, Duda JE, Grossman M, Hurtig HI, Aarsland D, Boeve BF, Brooks DJ, Dickson DW, Dubois B, Emre M, et al. 2007. DLB and PDD boundary issues: diagnosis, treatment, molecular pathology, and biomarkers. Neurology 68: $812-819$.

Mark MH, Dickson DW, Sage JI, Duvoisin RC. 1996. The clinicopathologic spectrum of Lewy body disease. Adv Neurol 69: 315-318.

Mata IF, Yearout D, Alvarez V, Coto E, de Mena L, Ribacoba R, Lorenzo-Betancor O, Samaranch L, Pastor P, Cervantes S, et al. 2011. Replication of MAPT and SNCA, but not PARK16-18, as susceptibility genes for Parkinson's disease. Mov Disord 26: 819-823.

McCann H, Stevens CH, Cartwright H, Halliday GM. 2014. $\alpha$-Synucleinopathy phenotypes. Parkinsonism Relat Disord 20: S62-S67.

Nalls MA, Pankratz N, Lill CM, Do CB, Hernandez DG, Saad M, DeStefano AL, Kara E, Bras J, Sharma M, et al. 2014. Large-scale meta-analysis of genome-wide association data identifies six new risk loci for Parkinson's disease. Nat Genet 46: 989-993. 
R.L. Nussbaum

Narhi L, Wood SJ, Steavenson S, Jiang Y, Wu GM, Anafi D, Kaufman SA, Martin F, Sitney K, Denis P, et al. 1999. Both familial Parkinson's disease mutations accelerate $\alpha$-synuclein aggregation. J Biol Chem 274: 9843-9846.

Pasanen P, Myllykangas L, Siitonen M, Raunio A, Kaakkola S, Lyytinen J, Tienari PJ, Pöyhönen M, Paetau A. 2014. Novel $\alpha$-synuclein mutation A53E associated with atypical multiple system atrophy and Parkinson's disease-type pathology. Neurobiol Aging 35: 2180.e1-2180.e5.

Peelaerts W, Baekelandt V. 2016. a-Synuclein strains and the variable pathologies of synucleinopathies. J Neurochem 139: $256-274$.

Petrucci S, Ginevrino M, Valente EM. 2016. Phenotypic spectrum of $\alpha$-synuclein mutations: New insights from patients and cellular models. Parkinsonism Relat Disord 22: S16-S20.

Pollanen MS, Dickson DW, Bergeron C. 1993. Pathology and biology of the Lewy body. J Neuropath Exper Neurol 52: $183-191$.

Polymeropoulos MH, Higgins JJ, Golbe LI, Johnson WG, Ide SE, Di Iorio G, Sanges G, Stenroos ES, Pho LT, Schaffer AA, et al. 1996. Mapping of a gene for Parkinson's disease to chromosome 4q21-q23. Science 274: 1197-1199.

Polymeropoulos MH, Lavedan C, Leroy E, Ide SE, Dehejia A, Dutra A, Pike B, Root H, Rubenstein J, Boyer R, et al. 1997. Mutation in the $\alpha$-synuclein gene identified in families with Parkinson's disease. Science 276: 20452047.

Poulopoulos M, Levy OA, Alcalay RN. 2012. The neuropathology of genetic Parkinson's disease. Mov Disord 27: $831-842$.

Prusiner SB, Woerman AL, Mordes DA, Watts JC, Rampersaud R, Berry DB, Patel S, Oehler A, Lowe JK, Kravitz SN, et al. 2015. Evidence for $\alpha$-synuclein prions causing multiple system atrophy in humans with parkinsonism. Proc Natl Acad Sci 112: E5308-5317.

Puschmann A, Wszolek ZK, Farrer M, Gustafson L, Widner H, Nilsson C. 2009. $\alpha$-Synuclein multiplications with parkinsonism, dementia or progressive myoclonus? Parkinsim Relat Disord 15: 390-392.

Safar J, Wille H, Itri V, Groth D, Serban H, Torchia M, Cohen FE, Prusiner SB. 1998. Eight prion strains have $\operatorname{PrP}^{\mathrm{Sc}}$ molecules with different conformations. Nat Med 4: 1157-1165.

Satake W, Nakabayashi Y, Mizuta I, Hirota Y, Ito C, Kubo M, Kawaguchi T, Tsunoda T, Watanabe M, Takeda A, et al. 2009. Genome-wide association study identifies common variants at four loci as genetic risk factors for Parkinson's disease. Nat Genet 41: 1303-1307.
Simón-Sánchez J, Schulte C, Bras JM, Sharma M, Gibbs JR, Berg D, Paisan-Ruiz C, Lichtner P, Scholz SW, Hernandez DG, et al. 2009. Genome-wide association study reveals genetic risk underlying Parkinson's disease. Nat Genet 41: 1308-1312.

Singleton AB, Farrer M, Johnson J, Singleton A, Hague S, Kachergus J, Hulihan M, Peuralinna T, Dutra A, Nussbaum R, et al. 2003. $\alpha$-Synuclein locus triplication causes Parkinson's disease. Science 302: 841.

Spillantini MG, Schmidt ML, Lee VM, Trojanowski JQ, Jakes R, Goedert M. 1997. $\alpha$-Synuclein in Lewy bodies. Nature 388: 839-840.

Spillantini MG, Crowther RA, Jakes R, Cairns NJ, Lantos PL, Goedert M. 1998. Filamentous $\alpha$-synuclein inclusions link multiple system atrophy with Parkinson's disease and dementia with Lewy bodies. Neurosci Lett 251: 205-208.

Tambasco N, Nigro P, Romoli M, Prontera P, Simoni S, Calabresi P. 2016. A53T in a parkinsonian family: A clinical update of the SNCA phenotypes. J Neural Transm (Vienna) 123: 1301-1307.

Tan EK, Matsuura T, Nagamitsu S, Khajavi M, Jankovic J, Ashizawa T. 2000. Polymorphism of NACP-Rep1 in Parkinson's disease: An etiologic link with essential tremor? Neurology 54: 1195-1198.

Ueda K, Fukushima H, Masliah E, Xia Y, Iwai A, Yoshimoto M, Otero DA, Kondo J, Ihara Y, Saitoh T. 1993. Molecular cloning of cDNA encoding an unrecognized component of amyloid in Alzheimer disease. Proc Natl Acad Sci 90: 11282-11286.

Wakabayashi K, Hayashi S, Kakita A, Yamada M, Toyoshima Y, Yoshimoto M, Takahashi H. 1998. Accumulation of $\alpha$ synuclein/NACP is a cytopathological feature common to Lewy body disease and multiple system atrophy. Acta Neuropathol 96: 445-452.

Wenning GK, Krismer F. 2013. Multiple system atrophy. Handb Clin Neurol 117: 229-241.

* Woerman AL, Watts JC, Aoyagi A, Giles K, Middleton LT, Prusiner SB. 2017. $\alpha$-Synuclein: Multiple system atrophy prions. Cold Spring Harb Perspect Med doi: 10.1101/ cshperspect.a024588.

Yoshimoto M, Iwai A, Kang D, Otero DAC, Xia Y, Saitoh T. 1995. NACP, the precursor protein of the non-amyloid $\beta / \mathrm{A} 4$ protein $(\mathrm{A} \beta)$ component of Alzheimer disease amyloid, binds $\mathrm{A} \beta$ and stimulates $\mathrm{A} \beta$ aggregation. Proc Natl Acad Sci 92: 9141-9145.

Zarranz JJ, Alegre J, Gómez-Esteban JC, Lezcano E, Ros R, Ampuero I, Vidal L, Hoenicka J, Rodriguez O, Atarés B, et al. 2004. The new mutation, E46K, of $\alpha$-synuclein causes Parkinson and Lewy body dementia. Ann Neurol 55: 164-173. 


\section{$\&_{\mathrm{CSH}}^{\infty} \&$ Cold Spring Harbor

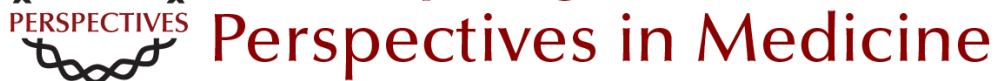

\section{Genetics of Synucleinopathies}

Robert L. Nussbaum

Cold Spring Harb Perspect Med 2018; doi: 10.1101/cshperspect.a024109 originally published online February 17, 2017

\section{Subject Collection Prion Diseases}

TDP-43 Prions

Takashi Nonaka and Masato Hasegawa

$\alpha$-Synuclein: Multiple System Atrophy Prions

Amanda L. Woerman, Joel C. Watts, Atsushi

Aoyagi, et al.

Genetics of Synucleinopathies

Robert L. Nussbaum

$\beta$-Amyloid Prions and the Pathobiology of

Alzheimer's Disease Joel C. Watts and Stanley B. Prusiner

Disease Mechanisms of C9ORF72 Repeat Expansions

Tania F. Gendron and Leonard Petrucelli

Chronic Traumatic Encephalopathy: Is Latency in

Symptom Onset Explained by Tau Propagation? Joshua Kriegel, Zachary Papadopoulos and Ann C. McKee

Noncerebral Amyloidoses: Aspects on Seeding,

Cross-Seeding, and Transmission

Gunilla T. Westermark, Marcus Fändrich,

Katarzyna Lundmark, et al.

Structural and Chemical Biology of Presenilin

Complexes

Douglas S. Johnson, Yue-Ming Li, Martin

Pettersson, et al.
Cell Biology and Pathophysiology of $\alpha$-Synuclein Jacqueline Burré, Manu Sharma and Thomas C. Südhof

Molecular Mechanisms of Chronic Wasting

Disease Prion Propagation Julie A. Moreno and Glenn C. Telling

Genetics of Amyotrophic Lateral Sclerosis Mehdi Ghasemi and Robert H. Brown, Jr.

The Genetics of C9orf72 Expansions Ilse Gijselinck, Marc Cruts and Christine Van Broeckhoven

Prion-Like Characteristics of

Polyglutamine-Containing Proteins Margaret M.P. Pearce and Ron R. Kopito

Therapeutic Strategies for Restoring Tau Homeostasis

Zapporah T. Young, Sue Ann Mok and Jason E. Gestwicki

Fused in Sarcoma Neuropathology in Neurodegenerative Disease Ian R.A. Mackenzie and Manuela Neumann

Experimental Models of Inherited PrP Prion

Diseases

Joel C. Watts and Stanley B. Prusiner

For additional articles in this collection, see http://perspectivesinmedicine.cshlp.org/cgi/collection/ 